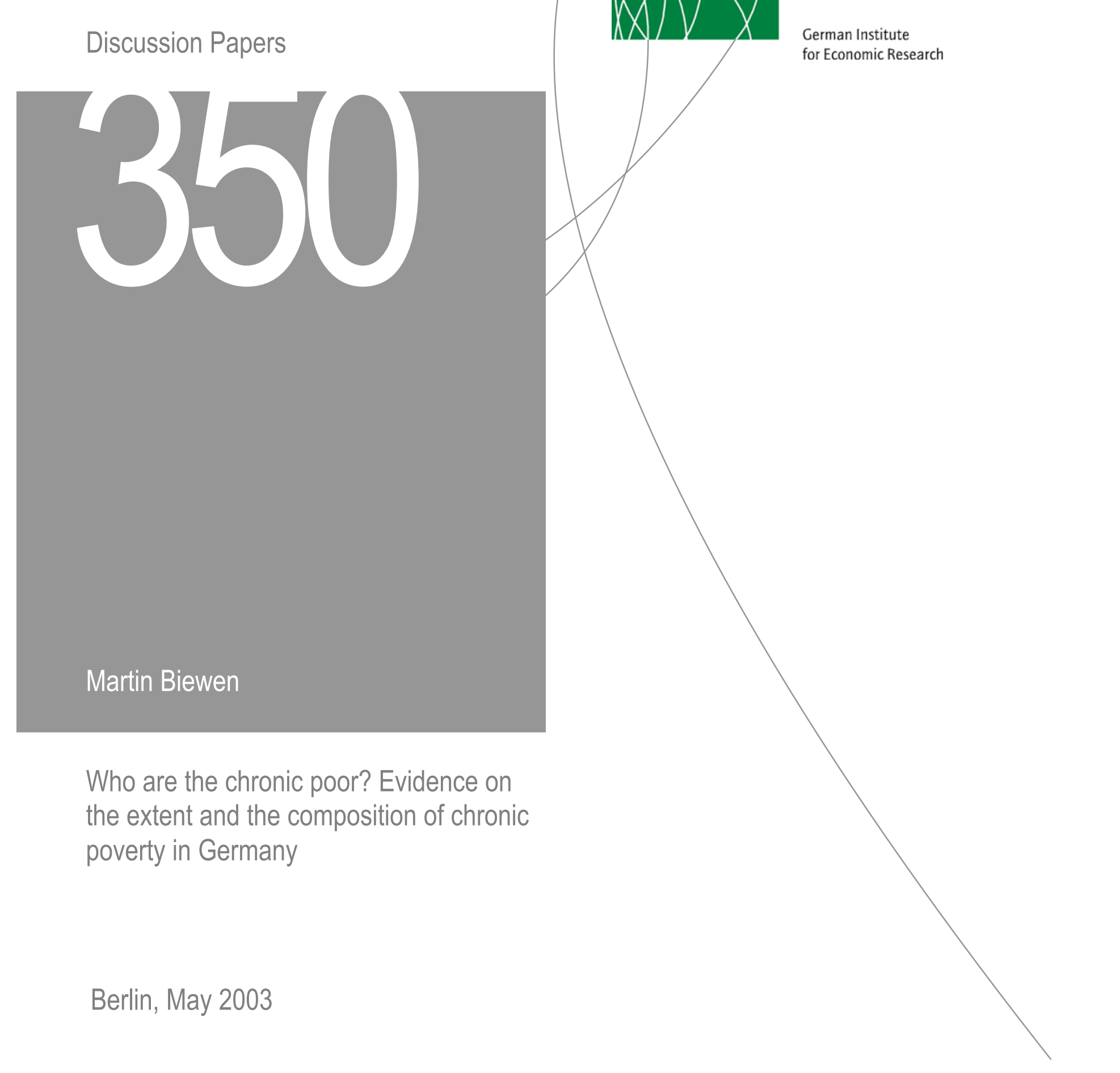


Opinions expressed in this paper are those of the author and do not necessarily reflect views of the Institute.

\section{DIW Berlin}

\section{German Institute}

for Economic Research

Königin-Luise-Str. 5

14195 Berlin,

Germany

Phone +49-30-897 89-0

Fax +49-30-897 89-200

www.diw.de

ISSN 1619-4535 


\title{
Who are the chronic poor? Evidence on the extent and the composition of chronic poverty in Germany ${ }^{1}$
}

\section{Martin Biewen}

University of Mannheim

IZA, Bonn

DIW Berlin

This version: 08 May 2002

\begin{abstract}
Based on a multiple spells approach, this paper studies the extent and the composition of chronic poverty in Germany. The results indicate that about one third of cross-sectional poverty in a given year is chronic. The characteristics that are most closely associated with long-term poverty are economic inactivity and pensioner status, while the number of children and the gender of the household head do not seem to have a systematic effect. This is in contrast to cross-sectional results where the biggest poverty risk is usually unemployment and a large number of children, while pensioners do not face particularly high poverty risks. Estimates from a multiple spells hazard model further suggest that $6 \%$ of the population have unobserved characteristics that lead to low poverty exit and high re-entry rates, making these individuals likely candidates for chronic poverty. A comparison with results for Great Britain and the United States suggests that poverty is less persistent in Germany.
\end{abstract}

JEL-Classification: C23, D31, I32

Keywords: chronic poverty, poverty persistence, multiple spells, unobserved heterogeneity

Correspondence:

Martin Biewen, Department of Economics, University of Mannheim, Verfügungsgebäude L7, 3-5, 68131 Mannheim, Germany, Fax: +49-621-1811841, biewen@rhein.vwl.uni-mannheim.de

\footnotetext{
${ }^{1}$ I would like to thank Francesco Devicienti for helpful discussions. The data used in this paper were made available by the German Socio Economic Panel Study (GSOEP) at the German Institute for Economic Research (DIW), Berlin. Financial support of the Deutsche Forschungsgemeinschaft (DFG) is gratefully acknowledged.
} 


\section{Introduction}

It is well known that cross-sectional snapshots of poverty provide only an incomplete picture of the amount and the incidence of poverty in a population. Knowing that 10 percent of the population are poor in a given year leaves open the question whether for these individuals poverty is a persistent phenomenon or just a temporary episode. For a number of reasons, the persistent or long-term part of poverty should draw more attention than the purely transitory one. Firstly, for the affected individuals long periods of low income lead to larger welfare losses and detrimental effects on self-perception and self-confidence than temporary or one-time poverty experiences. Secondly, the existence of long poverty spells means that the burden of poverty is unequally distributed in the population because the bulk of total poverty is borne by few individuals compared to the case where a larger number of individuals experience only short poverty spells. And thirdly, for the same reason, those who suffer from long-term poverty will consume a large part of the resources devoted to anti-poverty policy.

It is important to note that all of the above arguments not only apply to long single spells of poverty but also to unconnected multiple poverty experiences. It would therefore be to narrow to define the persistent part of poverty as the fraction of individuals who are in the midst of a long spell. This has been stressed by Stevens (1999) who explicitly considered the possibility that individuals who climbed out of poverty fall back in after some time above the poverty line. This perspective shifts the focus from the length of isolated spells to the sequence of multiple spells and the interrelationship of poverty exit and re-entry. Repeated spells of poverty with intermittent periods above the poverty line can be described as a form of 'chronic' poverty. Just as long single spells, repeated spells lead to a large total number of years spent below the poverty line over a given period of time, say ten years.

The aim of this paper is to study chronic poverty in Germany defined as the subpopulation of individuals who are poor in five or more years out of ten. This includes long single spells as well as repeated shorter or longer spells. The subpopulation of individuals who are poor in ten years out of ten will also be analyzed. The questions investigated are to what extent cross-sectional poverty is chronic, how the chronic poverty population is composed and how the temporal structure of chronic poverty experiences looks like. In particular, it is examined how poverty exit and re-entry rates are related to each other and to the time already spent in or out of poverty, and how individual and household characteristics influence these processes. 
Finally, a simulation approach is taken to calculate the number of years spent poor for different individuals with given characteristics.

The analysis presented here builds on previous work on poverty dynamics, in particular on Bane/Ellwood (1985), Stevens (1999) and Oxley et al. (2000). Bane/Ellwood (1985) were the first to introduce the spell-based approach into poverty measurement. Although they focused on single spells, the use of hazard models allowed them to gain new insights into the longitudinal structure of poverty. An important finding was that while most of those who fall into poverty will stay there for only a short time, the stock of the currently poor is made up to a large extent by individuals who are in the midst of a long spell. Bane/Ellwood (1985) were criticized by Stevens (1999) who pointed out that focussing on single spells systematically underestimates poverty persistence as the possibility of re-entry is ignored. In order to take account of multiple spells she presented a hazard model that allowed spell durations in and out of poverty to be correlated with each other via an unobserved heterogeneity term. ${ }^{2}$ Oxley et al. (2000) study poverty dynamics in six OECD countries, one of them Germany. They focus on the events associated with poverty transitions and also estimate duration models for poverty exit and reentry. While there is some overlap between their results and the ones presented here, the main difference is that the analysis here is based on more years, that better econometric techniques are $u_{s e d}{ }^{3}$ and that this paper has an explicit focus on the chronic part of poverty, including the possibility of multiple spells.

The rest of the paper is organized as follows. Section 2 describes the data, which was taken from the German Socio-Economic Panel (GSOEP). In section 3 the question is examined to what extent cross-sectional poverty can be regarded as chronic. Section 4 presents some results on the relationship of chronic poverty status and household characteristics. In section 5 , a discrete time hazard model is estimated that relates exit and re-entry rates to individual characteristics. The results from this model are used in section 6 to simulate the average time spent below the poverty line for individuals with given characteristics. Section 6 concludes.

\footnotetext{
${ }^{2}$ Following Stevens (1999), Devicienti (2001) and Jenkins/Rigg (2001) used the same model to analyze poverty persistence in Britain.

${ }^{3}$ For example, Oxley et al. (2000) do not control for unobserved heterogeneity and they do not estimate joint models of exit and re-entry allowing for correlation across spells. Moreover, this paper shows how correct standard errors taking into account clustering of observations at the household level can be computed if halfsamples as in Stevens (1999) are not available. This is also pointed out as a topic for future research by Devicienti (2001).
} 


\section{Data}

The following analysis is based on data from the German Socio-Economic Panel (GSOEP). The GSOEP is one of the longest-running panels in the world. ${ }^{4}$ It was started in 1984 for West Germany and extended to East Germany after reunification in 1990. As a long panel is essential for the investigation of exit and re-entry conditional on the duration already spent in or out of poverty, the analysis focuses on West Germany only. The sample used here comprises the years 1984 through 2000.

The dependent variable of the analysis is individual poverty status derived from equivalized monthly net household income. ${ }^{5}$ Monthly net household income in the GSOEP is an estimate (provided by the household head) of total income of all household members, inclusive of transfers and after deduction of taxes and social security contributions. As equivalence scale, the widely used new OECD-scale was applied. This scale normalizes household income by the square-root of household size. An individual was counted as poor if his or her equivalent income fell below the poverty line, which was fixed at 50 percent of contemporaneous mean income. ${ }^{6}$

As potential covariates of chronic poverty status and poverty transitions individual age and a number of household characteristics were considered. The idea behind individual age as a covariate is to measure the incidence of long-term poverty across age groups. However, as poverty status is based on household income, it is generally more interesting to consider household characteristics than individual characteristics. For this reason, the employment status of the household head, information on his or her educational qualification, nationality and gender, as well as the number of children and other earners in the household were also included. In particular, it was used whether the household head was gainfully employed (full time or part time) or retired and whether he or she had as highest educational qualification a university degree, Abitur (comparable to a high school graduation certificate) or Lehre (vocational training).

The selected samples comprise all original GSOEP sample members, including children and foreigners (GSOEP-sample B). As some individuals entered the panel in the years after 1984

\footnotetext{
${ }^{4}$ For more information on the GSOEP, see SOEP-Group (2001) and Haisken-DeNew/Frick (2001).

${ }^{5}$ Available evidence suggests that using yearly income instead of monthly income yields similar results, see Otto/Siedler (2003). Using monthly income (from the survey month) mitigates the problem that household level variables may change during the relatively long period of one year.

${ }^{6}$ This is a conventional standard for Germany. It has been used in numerous studies, see e.g. Hauser (1997), Becker (1997), Bundesministerium für Arbeit und Sozialordnung (2001), Krause (2001) and Otto/Siedler (2002).
} 
and some dropped out temporarily or for good before 2000, the sample is an unbalanced one. If the individual dropped out temporarily then all information collected after this temporary drop-out was discarded. The analysis uses two kinds of samples, one including left-censored spells and another one omitting them. Leftcensored spells had to be dropped whenever full information on the time already spent in or out of poverty was required. ${ }^{7}$ In the case without leftcensored spells the sample was selected so that an individual's record consisted of his or her first contiguous sequence of poverty/non-poverty spells, starting with the first fresh poverty or non-poverty spell. If the first fresh spell was one of non-poverty then this automatically implied previous poverty experience (otherwise the non-poverty spell would be left-censored). This means that entry into poverty as observed in the sample was always re-entry.

In order to mitigate biases arising from the different length and timing of individual poverty histories, these were weighted by their inverse longitudinal inclusion probability. The probability that an individual was present in the longitudinal sample for a number of periods is given by the product of its selection probability in the wave it was first observed and the staying probability in each subsequent wave. As estimates for both kinds of probabilities are provided in the GSOEP, calculation of these weights is straightforward. (For more details, see Haisken-DeNew/Frick (2001), pp. 146 - 148.) Using these weights accounts to a certain extent for panel attrition as the estimation of the staying probabilities is based on an attrition model.

Another problem concerns the correlation between observations of individuals from the same household. Due to the use of household information stochastic variation is only independent between individuals who did not live together in the same household at any point during the sample period. This problem is addressed by forming clusters of individuals who did not belong to the same household at any point during their contributed poverty/non-poverty sequences. The clusters are defined so that individuals who did live together at some point belong to the same cluster. If two individuals belong to the same cluster but have not lived together then there exists a sequence of individuals connecting the two individuals in which adjacent individuals have lived together at some point. 8 The information on the clusters can then be used to calculate standard errors and confidence intervals that impose no restriction on the correlation of observations within clusters.

\footnotetext{
${ }^{7}$ This means that individuals who were poor in every period were not included in this kind of sample. Given the length of the panel, this concerned only a tiny fraction of the data.

${ }^{8}$ See Biewen (2002) for more details.
} 


\section{How much chronic poverty is there?}

The aim of this section is to get a first impression of the extent of chronic poverty. Three questions are addressed: 1) What fraction of the currently poor are chronically poor? 2) What fraction of those just starting a poverty spell face a career of chronic poverty? And 3) How large is the share of the chronic poor in the overall population? In the following, an individual is defined as being chronically poor if he or she is poor in five or more years out the next ten. As long single spells of poverty are also of interest, individuals experiencing spells of five or more years are also analyzed. Finally, results for the subpopulation of the 'permanently' poor, i.e. who are poor in every year over a period of ten years are also presented.

Figure 1 shows the evolution of cross-sectional poverty rates from 1984 to 2000. It can be seen that over this period between eight and ten percent of the population in each year had incomes below the poverty line. There seems to be a close relationship between the current poverty rate and the state of the business cycle. The poverty rate fell during the long period with positive GNP growth from the mid eighties to the beginning of the nineties and rose after the recession of 1993. Toward the end of the nineties poverty rates developed unsteadily.

The fraction of those currently poor who were chronically and/or long-term poor is presented in Figure 2. The fraction of individuals who were poor five or more years out of the next ten rose from about $25 \%$ in 1984 to some $37 \%$ in 1990. A possible explanation for this rising trend is that the fall in the overall poverty rate during that period mainly reduced transitory poverty, increasing the share of those persistently poor. However, the increase can also be explained by the fact that rising poverty rates after 1992 increased the risk for individuals to be poor in more than five years out of the coming ten. At about $35 \%$, the fraction of those who were in the midst of a lengthy spell of five or more years was of a similar magnitude. The falling trend in this number might be due to the fact that rising poverty rates first manifest themselves in a larger share of short spells if they are caused by an increased inflow. Only 5 $\%$ of the currently poor were poor in every year over a period of ten years. This fraction was remarkably stable. Taken together, the results suggest that about $30 \%$ of poverty in a given year was chronic.

The next question investigated is how many of those just starting a poverty spell face a career of chronic poverty. This question can be addressed by estimating exit and re-entry rates conditional on the duration already spent in or out of poverty. For example, the poverty 
exit rate can be estimated as $E(d)=x(d) / y(d)$, where $x(d)$ is the total number of exits in the population after $d$ periods in poverty and $y(d)$ is the total number of situations where an individual has spent $d$ periods in poverty. ${ }^{9}$ The re-entry rate into poverty after $d$ periods out of poverty is estimated similarly.

Estimates of both rates are given in Figures 3 and 4. Figure 3 shows that more than 50 percent of individuals who become poor are able to escape this situation within one year. The fraction of those leaving poverty declines more or less continuously as the time already spent there increases. After 4 years only 20 percent exit per period and only 10 percent after 9 years. After 12 or more years, no one in the sample was observed to exit poverty. There are interesting spikes at durations 5 and 10 years, which are indistinguishable from sampling error, but which might suggest that individuals who reach these durations take extra measures to escape their situation. Looking at the re-entry rates in Figure 4 one can see that some 20 percent of those having exited poverty fall back in within one year. The danger of recidivism gets the smaller the longer the individual has stayed out of poverty. After 3 years, only 10 percent fall back in, after 4 years it is only 5 percent. Those who manage to stay out for more than 10 years do not tend to fall back in anymore.

From the exit and re-entry rates one can calculate the distribution of years spent poor out the next ten. This is done by summing over all possible sequences of poverty/non-poverty spells over ten years. For example, the probability for the sequence $s=(P, N, P, P, P, N, P, P, N, N)$ is given by $P(s)=E(1) R(1)(1-E(1))(1-E(2)) E(3) R(1)(1-E(1)) E(2)(1-R(1))$, where $P, N$ denotes poverty and non-poverty, respectively. For a cohort of individuals just starting a poverty spell, the probability of experiencing four years in poverty over the next ten years is then given by the sum over all possible sequences $(P, x, x, x, x, x, x, x, x, x)$ with exactly four years in poverty.

The results of this exercise are shown in Table 1. The distribution of periods spent poor can be compared to the one from a single spell approach. As expected, the probability of a large number of years spent poor is much lower if re-entry into poverty is ignored. However, the

\footnotetext{
${ }^{9}$ In terms of the data used here, $x(d)=\sum_{j=1}^{n_{c}} \sum_{l \in C_{j}} w_{l}$ [\# of exits after $d$ periods of individual $\left.l\right]$ and $y(d)=$ $\sum_{j=1}^{n_{c}} \sum_{l \in C_{j}} w_{l}$ [\# of situations with $d$ of individual $l$ ], where $w_{l}$ denotes the sample weight of individual $l, C_{j}$ the $j$-th cluster and $n_{c}$ the total number of clusters. $E(d)$ is a so-called ratio-estimator and its variance is estimated as $\widehat{\operatorname{var}}(E(d))=x(d)^{-2}\left[\widehat{\operatorname{var}}(y(d))-2 E(d) \widehat{\operatorname{cov}}(y(d), x(d))+E(d)^{2} \widehat{\operatorname{var}}(x(d))\right]$ where $\widehat{\operatorname{var}}(\cdot)$ and $\widehat{\operatorname{cov}}(\cdot)$ are appropriate variance and covariance estimates for $x(d)$ and $y(d)$, see e.g. Deaton (1997), p.49. The latter are also used at several points in the rest of the paper.
} 
predictions of the multiple spell approach are generally not closer to the number of years spent poor as observed in the sample (column 3). In particular, the multiple spell approach seems to overestimate the probability of a large number of years spent poor.

According to the multiple spell calculations, those just starting a poverty spell will be poor for almost four years out of ten on average. The fraction of those chronically poor (five or more years poor out of ten) is about one third. However, they bear the bulk of overall poverty measured in person-years (63\%, see last row of Table 1). Note that the fraction of those facing chronic poverty in the sample (about $16 \%$ ) is much lower than in the multiple spell approach. However, the multiple spell calculations are probably more reliable in this context since the estimates from the sample are directly affected by right-censoring of spells due to panel attrition, whereas right-censored spells still contribute to the estimation of exit and re-entry rates.

The final question studied in this section is how many individuals in the overall population suffer from chronic poverty. ${ }^{10}$ This is addressed by looking at the unconditional distribution of the number of years spent poor out of the next ten given in Table 2. According to the estimates, 75 - $82 \%$ of the population do not fall into poverty at all in a period of ten years. The population share of the chronic poor (five or more years poor out of ten) is relatively low (two to three percent) if measured directly in the sample and higher (seven percent) when multiple spell calculations are carried out. ${ }^{11}$ The true value probably lies somewhere between these numbers as the direct estimates are downward-biased by attrition and the multiple spell simulations based on homogenous and time-invariant transition probabilities are only a crude model of poverty transitions. ${ }^{12}$

According to the direct estimates from the sample, about one third of overall poverty (measured in person-years) over ten years is borne by the two to three percent of chronic poor. This is another way to look at the results at the beginning of this section, where it was found that about $30 \%$ of those currently poor were also chronically poor. If one assumes that the composition of the currently poor is constant over time (i.e. in a stationary state) then

\footnotetext{
${ }^{10}$ Note that this does not directly follow from the results presented at the beginning of the section, as an individual may belong to the chronic poverty population without being poor in a given year.

${ }^{11}$ For that purpose the number of years spent poor was simulated using the estimated exit and re-entry rates and an initial distribution of poverty status and poverty/non-poverty duration as measured in the year 2000 .

${ }^{12}$ These assumptions will be relaxed in Section 5 .
} 
the probability that a randomly drawn person-year of poverty belongs to a chronically poor individual is $33 \%$, or in other words, $33 \%$ of those poor in a given year are chronically poor. This is very close to the $30 \%$ reported above.

\section{Chronic poverty and household characteristics}

Having established that about one third of those currently poor face extended or repeated periods in poverty, the next question is how this group is composed and how their status is related to personal characteristics. Evidence on the these questions is presented in Tables 3a and 3b. The difficulty here is that personal characteristics can change over time and typically do so, making it difficult to characterize individuals who belong to a certain longitudinal population (here the chronic poor). The problem is basically addressed by looking at how long during the period under consideration ${ }^{13}$ an individual had certain characteristics. In addition, it is considered whether the individual in question always had these characteristics when poor and whether he or she started a particularly long spell with them.

The first set of results in Table 3a shows that about $50 \%$ of the individuals who started a long spell (five years or more) lived in a female headed household when the spell began. This was a much higher number than the corresponding fraction in the overall population, which was $20 \%$ (column 2). Also, almost all of these individuals (again $50 \%$ of those with long spells) seemed to stay in a female headed household during most of the spell (in at least $80 \%$ of the time). Some three percent were part of such a household during $50-80 \%$ of the spell length, leaving $47 \%$ who were never or only sometimes part of a female headed household when experiencing a poverty spell of five or more years.

Similarly, $35 \%$ of those poor five or more years out of ten belonged to a female headed household during most of the time (in at least eight years out of ten), $21 \%$ lived in such a household during five, six or seven years out of ten, and some $52 \%$ in all the years they were poor. Individuals from female headed households were also over-represented among those poor ten years out of ten, where $66 \%$ belonged to this subpopulation throughout the whole ten years (i.e. whenever they were poor and in $100 \%$ of the time, see last column of Table 3a). However, due to the small size of this subpopulation, standard errors are quite large in this case.

\footnotetext{
${ }^{13}$ This is the spell length in the case of long spells and a period of ten years in all other cases.
} 
As to the number of workers in a household, the results suggest that individuals from households with no workers represent the largest fraction of the chronic poverty population. This is true both for long spells, where $71 \%$ came from a workless household at the spell beginning, and for chronic poverty status, where $53 \%$ lived in such a household whenever they were poor. On the other hand, individuals from households with one or more worker were clearly under-represented. Even in the case with only one worker, only $7 \%$ of those chronically poor belonged to such a household in most of the periods over ten years. This shows that there is clearly no phenomenon of the 'working poor' in Germany.

With regard to household types, single adult and single parent households were more frequent among the chronic poor than their population share suggests. For example, $29 \%$ of those starting a long poverty spell lived in a single household and $29 \%$ were single whenever they were poor over a period of 10 years. At $16 \%$, the share of individuals from lone parent households (mostly lone mothers) among those just beginning a long spell was far above the corresponding population share of two percent. Apparently, most of these individuals (14\% of those experiencing a long spell) also stayed in a lone parent household during most of the spell length. This suggests that lone parents and their children not only faced a high risk being poor in a given year but also the risk of staying there for an extended period of time.

Consistent with the findings for number of workers in the household, cases where the household head was employed at the beginning of a long spell or most of the time during a period of chronic poverty were comparatively rare. Surprisingly, they were also relatively rare for individuals from households with unemployed heads. Only $17 \%$ of the individuals starting a long spell belonged to such a household at the beginning of the spell and only six percent had an unemployed head whenever they were poor during a period of chronic poverty. This was not much more than their population share in a given year $(5 \%)$. Also note that only half of those starting a long spell with unemployment stayed there during most of the spell. This means that in many cases unemployment status was associated with the beginning of a long spell but did not last long enough to completely account for it. The fact that many of these individuals remained poor even when not unemployed anymore suggests that they retreated from the labor rather than finding employment.

The results also show that pensioner households represented a large stable fraction of the long-term poor (almost one third), much larger than their population share of $17 \%$. As retirement status tends to be time-invariant from a certain age on, most of these individuals 
stayed retired during most of the time they were poor. The residual group of individuals where the household head was economically inactive (this also included full-time students) was clearly over-represented among those starting a long spell. This was not necessarily the case in the group of those experiencing at least five years in the poverty out of ten, suggesting again that their status was likely to change over such a period.

The tabulations for educational qualifications in Table $3 \mathrm{~b}$ demonstrate that individuals from households with university educated heads were completely absent in the population of the long-term poor. Low educational qualifications were slightly over-represented, while medium qualifications were slightly under-represented. As to the number of children in the household, over $50 \%$ of the long-term poor had no children most of the time, but this also corresponded to their population share. In general, the number of children appeared to have little association with chronic poverty status, which is in contrast to cross-sectional results. ${ }^{14}$

Similarly, being a child was no reason to be particularly vulnerable to chronic poverty. Only $19 \%$ of the chronically poor were below 18 years of age in periods of poverty, less than the corresponding population share of $23 \%$. This is also in contrast to cross-sectional results, where children usually have higher poverty risks. Individuals aged between 18 and 64 years were clearly under-represented among the long-term poor. The only age group suffering from a relatively high risk of chronic poverty were those aged over 64 years. For example, $24 \%$ of those starting a long spell belonged to this age group throughout the duration of the spell, compared to $10 \%$ in the overall population. This is explained by the fact that, once poor, pensioners do not have many possibilities to change their situation.

All these findings appear in more extreme form in the results for the group of the 'permanently' poor (ten years poor out of ten) shown in the last column of Tables 3a and 3b. It turns out that this subpopulation mostly consists of individuals from female headed households, from households without gainfully employed members or children, single households and households where the head is retired.

Taken together, a large part of the long-term poor came from female headed households and households without gainfully employed members. Single parents were also over-represented but due to their small population share made up only a minority of the chronic poor. An

\footnotetext{
${ }^{14}$ For the correlates of cross-sectional poverty risk in Germany, see Hauser (1997), Bundesministerium für Arbeit und Sozialordnung (2001) and Biewen/Jenkins (2001).
} 
interesting finding is that some groups who generally face particularly high or particularly low poverty risks in a cross-section did not so with respect to long-term poverty. For example, while pensioner households usually do not suffer from particularly high poverty risks in a crosssection, they were clearly over-represented in the subpopulation of the long-term poor. Similarly, individuals affected by unemployment and households with many children usually face a high risk of being poor in a cross-section, but they were not over-represented in the longitudinal population of the chronic poor.

In general, a clear characterization of the long-term poor in terms of personal characteristics is encumbered by the fact that characteristics tend to change over longer periods, making it hard to determine a clear association between them and an extended poverty experience. In fact, in most cases the majority of individuals could not be described by the same characteristic throughout a period of chronic poverty.

\section{$5 \quad$ A multiple spell hazard model}

A drawback of the results in the previous section is that only the association of one household characteristic at a time with chronic poverty status is considered. In order to gain more insights into how poverty duration and the number of years spent poor are related to personal characteristics, poverty exit and re-entry rates are modelled conditional on a number of characteristics and the duration already spent in the corresponding state. As it is unlikely that all variables determining exit and re-entry can be included, it is important to control for unobserved heterogeneity. In that case it seems crucial to allow for the possibility that exit and re-entry are correlated, for example because individuals who have difficulty exiting poverty are more likely to fall back in for reasons that are related to each other but not observed. To address these questions the following hazard model has proven useful. ${ }^{15}$ The hazard rate of individual $i$ for leaving poverty in interview $j$ is specified as

$$
E_{i j}\left(d_{i, j-1} \mid \theta_{i}^{P}\right)=\Phi\left(\theta_{i}^{P}+\alpha\left(d_{i, j-1}\right)+x_{i, j-1}^{\prime} \beta\right)
$$

where $\theta_{i}^{P}$ is an individual random effect, $\alpha\left(d_{i, j-1}\right)$ a function of duration in poverty and $x_{i, j-1}$, $\beta$ individual characteristics (from the previous period) and a parameter vector. $(\Phi(\cdot)$ is the

\footnotetext{
${ }^{15}$ The model goes back at least to Meghir/Whitehouse (1997). In the poverty context, it has been used by Stevens (1999), Devicienti (2001) and Jenkins/Rigg (2001).
} 
normal distribution function.) Similarly, the hazard rate for re-entry is given by

$$
R_{i j}\left(d_{i, j-1} \mid \theta_{i}^{N}\right)=\Phi\left(\theta_{i}^{N}+\kappa\left(d_{i, j-1}\right)+x_{i, j-1}^{\prime} \gamma\right)
$$

with $\theta_{i}^{N}$ being a random effect for re-entry, $\kappa\left(d_{i, j-1}\right)$ a function of the time spent out of poverty and $z_{i, j-1}, \gamma$ individual characteristics and a parameter vector as before.

The inclusion of poverty and non-poverty duration as a regressor makes it necessary to start the sampling of an individual's poverty history with his or her first fresh poverty or non-poverty spell. In this context, selection into poverty or non-poverty at the beginning of the observation period is not random but depends on individual characteristics including the unobserved heterogeneity terms. This can be accounted for by adding a term for the probability that the first fresh spell is one of poverty, i.e.

$$
P_{i 1}\left(q_{i}\right)=\Phi\left(q_{i}+v_{i}^{\prime} \phi\right)
$$

with a random effect $q_{i}$, individual characteristics $v_{i}$ and a parameter vector $\phi$.

As $P_{i 1}$ can be seen as the reduced form of the first observed fresh spell, which - according to the model - depends on past information, ${ }^{16} w_{i}$ should include characteristics from the period in which the first fresh spell began as well as presample information. The correlation of the unobserved parts in the initial equation and in the exit and re-entry rates is then modelled by assuming a joint distribution for $q_{i}, \theta_{i}^{P}$ and $\theta_{i}^{N}$ with two points of support for each random effect. ${ }^{17}$ The random effects as well as their joint distribution $p_{k l m}=P\left(q_{i}=q_{k}, \theta_{i}^{P}=\theta_{l}^{P}, \theta_{i}^{N}=\right.$ $\left.\theta_{m}^{N}\right)$ can then be treated as free parameters in the estimation procedure. ${ }^{18}$

Estimates of $q_{k}, \theta_{i}^{P}, \theta_{i}^{N}$ and $\phi, \alpha(\cdot), \beta, \kappa(\cdot), \gamma$ are obtained by maximizing the PseudoLikelihood function

$$
\begin{aligned}
\log L=\sum_{i=1}^{N} w_{i} \log \{ & \sum_{k=1}^{K} \sum_{l=1}^{L} \sum_{m=1}^{M} p_{k l m}\left[P_{i 1}\left(q_{k}\right)^{p_{i 1}}\left(1-P_{i 1}\left(q_{k}\right)\right)^{1-p_{i 1}}\right] \\
& \times \prod_{j=2}^{J_{i}}\left[\left(1-E_{i j}\left(d_{i, j-1} \mid \theta_{l}^{P}\right)\right)^{1-e_{i j}} E_{i j}\left(d_{i, j-1} \mid \theta_{l}^{P}\right)^{e_{i j}}\right]^{p_{i, j-1}}
\end{aligned}
$$

\footnotetext{
${ }^{16}$ Compare Heckmann (1981).

${ }^{17}$ See Heckman/Singer (1984). Experiments with more than two points of support led to severe convergence problems and were not pursued further. None of the reported specifications in the literature use more than two support points.

${ }^{18}$ For estimation, the $p_{k l m}$ were reparametrized as $p_{\tau}=r_{\tau}^{2} /\left(1+\sum_{\tau=1}^{K L M-1} r_{\tau}^{2}\right)$ for $\tau=1 \ldots K L M-1$ and $r_{K L M}=1-\sum_{\tau=1}^{K L M-1} r_{\tau}$ so that $\sum_{k=1}^{K} \sum_{l=1}^{L} \sum_{m=1}^{M} p_{k l m}=1$ and $0 \leq p_{k l m} \leq 1$ for unrestricted $r_{\tau}$.
} 


$$
\left.\times\left[\left(1-R_{i j}\left(d_{i, j-1} \mid \theta_{m}^{N}\right)\right)^{1-e_{i j}} R_{i j}\left(d_{i, j-1} \mid \theta_{m}^{N}\right)^{e_{i j}}\right]^{1-p_{i, j-1}}\right\}
$$

where $K=L=M=2$ and $p_{i j}, e_{i j}$ are dummies indicating poverty status in interview $j$ and whether the individual changed its state between interviews $j-1$ and $j$. Standard errors taking into account longitudinal sample weights $w_{i}$ and the clustering of observations can be calculated using the methods described in Binder (1983) (also compare Skinner et al. (1989), pp. $80-83)$.

Estimates for this model are given in Table 4. Three variants of the model are presented, one without unobserved heterogeneity, one with unobserved heterogeneity, and one with unobserved heterogeneity and a term for the initial condition. In the reported specifications, $\alpha\left(d_{i, j-1}\right)$ and $\kappa\left(d_{i, j-1}\right)$ were specified as quadratic terms. Preliminary estimates with a full set of duration dummies led to similar patterns but generally large standard errors. As regressors for exit and re-entry, all of the so far discussed variables were originally considered, plus (alternatively) aggregate unemployment rates and dummies for the state of the business cycle. Many of these variables were not statistically significant and were therefore not kept in the specifications reported here.

Similar things can be said about the equation for the initial condition. As instruments for initial poverty status, a number of presample variables were considered, in particular information on parents' educational qualifications and job positions and where the individual in question grew up. However, none of these variables were statistically significant, and the reported specification was the most convincing one. In general, the estimates for the random effects and the distribution parameters were very imprecise when the initial condition was accounted for, suggesting either that selection into the initial state was unimportant or that the sample was too small to estimate such a complex model. ${ }^{19}$ For this reason, the discussion will focus on the specification without initial condition. ${ }^{20}$

The results for the preferred specification (column 2 of Table 4) indicate that even after controlling for observed and unobserved differences between individuals, there was negative duration dependence in poverty exit and re-entry behaviour. ${ }^{21}$ This could be explained by a

\footnotetext{
${ }^{19}$ Devicienti (2001) comes to similar conclusions.

${ }^{20}$ Stevens' (1999) original contribution did not explicitly model the initial state either.

${ }^{21}$ Of course, this result should be taken with a grain of salt as it strictly holds only if the random effects are sufficiently independent from the regressors.
} 
process of discouragement that makes it the harder for individuals to exit poverty the longer they have stayed there (and an analogous mechanism for re-entry). The age profile of exit and re-entry seemed relatively flat with a maximum at about 33 years for poverty exit and a minimum at 29 years for the probability of re-entry.

The pattern that the effects of a characteristic on poverty exit and re-entry had opposite signs could also be observed for most of the other regressors. Exit rates were higher if a household was headed by employed, retired, high or medium-skilled persons, and the probability of reentry was also lower for these groups of individuals. For exit, high educational qualifications of the head had the biggest effect, while employment status was most important for the probability of re-entry. The number of other earners also played a role, increasing the probability of exit and reducing the danger of re-entry. According to the estimates, the number of children and nationality had only a small effect and only so for re-entry.

The estimates of the distribution of unobserved heterogeneity shown at the bottom of Table 5 indicate that there were two types of individuals. The first type represented the large majority of the population (94\%) and was characterized by, other things equal, a high probability of exit and a low probability of re-entry. By contrast, the remaining $6 \%$ of the population seemed to have unobserved characteristics that made poverty exits difficult and recidivism likely. For comparison, results for a specification without unobserved heterogeneity are given in the first column of the table. While the effects of observables are not very different, the introduction of the unobserved heterogeneity terms makes a big difference at the individual level, as will be seen in the next section.

\section{Simulation results}

A good way to interpret the estimates from the hazard model is to study their implications for the time spent poor over ten years via simulation. For this purpose, transitions were simulated for a cohort of individuals with given observed and unobserved characteristics who were just starting a poverty spell. More precisely, latent variables

$$
\begin{aligned}
& I^{P}=\theta_{i}^{P}+\alpha\left(d_{i, j-1}\right)+x_{i, j-1}^{\prime} \beta+\epsilon_{i, j}^{P} \\
& I^{N}=\theta_{i}^{N}+\kappa\left(d_{i, j-1}\right)+x_{i, j-1}^{\prime} \gamma+\epsilon_{i, j}^{N}
\end{aligned}
$$


were computed for $i=1 \ldots 10000$ individuals and $j=1 \ldots 10$ years, given characteristics $\theta_{i}^{P}, \theta_{i}^{N}, x_{i, j-1}$ and i.i.d. random draws $\epsilon_{i, j}^{P}, \epsilon_{i, j}^{N} \sim \mathcal{N}(0,1)$. Except for age, all elements in $x_{i, j-1}$ were held fixed. A transition occurred if the corresponding latent variable was positive.

The results from this exercise are given in Tables $5 \mathrm{a}$ and $5 \mathrm{~b}$. The first set of results refers to the large subgroup with unobserved characteristics $\theta_{1}^{P}, \theta_{2}^{N}$ leading to high exit and low reentry probabilities ('high/low-type'). Comparing the average number of years spent poor for a child from a representative household (German nationality, medium-skilled, employed head, one child, no other earners, see row one of the table) with those for an adult (row 38) reveals that the age profile of long-term poverty was practically flat (2.26 vs. 2.10 years poor out of ten and 8 vs. $6 \%$ chronic poverty). Also note that these numbers are well below those observed on average in the sample (2.63 years and $16 \%$, see column 3 of Table 1 ).

Employment status of the head had a much larger impact. Non-employment of the head meant 3.68 vs. 2.07 years spent poor out of ten and 32 vs. $6 \%$ long-term poverty, measured for an individual aged 30 from a representative household with medium-skilled head and no other earners or children (rows 33 and 34). Similarly, if the head had high rather than low educational qualifications, the expected number of periods spent poor over ten years was 1.64 compared to 2.92 , and the risk of long-term poverty $1 \%$ compared to $19 \%$ in the case of low qualifications (rows 35 and 36 ).

The number of other earners played a moderate role. For example, the average number of years spent poor for an individual from a representative household (German nationality, medium-skilled, employed head, no children) was 2.10 compared to 1.43 if the household had two additional other earners. The fraction of long-term poverty in that case was 6 compared to $1 \%$ (rows 43 and 48). The number of children and nationality had only a small effect. Three children instead of none meant 2.24 vs. 2.10 years spent poor and 7 vs. $6 \%$ long-term poverty (rows 43 and 50), while non-German nationality of the household head was associated with 2.17 average years spent poor and $7 \%$ long-term poverty compared to 2.07 years and $6 \%$ when the head was German (e.g. rows 30 and 40). In the cases simulated here, typical pensioner households faced considerably more expected years in poverty (3 to 5 years) and higher risks of long-term poverty (23 to $46 \%$ ), except in the case of high qualifications (rows 63 to 66 ).

Altogether, the variation across different types of individuals simulated here was considerable, ranging from 1.64 expected years spent poor and $1 \%$ long-term poverty for a 30 year old person in a childless German household with a high-skilled and employed head (row 36), 
to 5.85 years and $68 \%$ for a small child from a non-German household with 2 children and a low-skilled non-employed head (row 12). The results also show that the influence of unobserved differences was even bigger than that of observed ones. For example, a medium-skilled employed individual aged 30 years (row 33) faced 2.07 expected years below the poverty line and a long-term poverty risk of $6 \%$ if he or she was of the 'high/low'-type, while a 'low/high'-type with the same characteristics faced an average 7.82 years and a long-term poverty risk of $96 \%$ !

Note that in the multivariate analysis presented in this section, there was no association of the gender of the household head with long-term poverty. This suggests that the relationship found in Table 3a was spurious in the sense that not gender per se but other characteristics correlated with it were important. In the light of the result in this section, this was most likely employment status of the household head. On the other hand, the absent association of chronic poverty with the number of children in the household (which is a common finding of crosssectional analyses) and the comparatively high long-term poverty risk of pensioners is in line with what was found in the longitudinal tabulations of the previous section.

\section{Conclusion}

This paper focussed on the extent and the composition of chronic poverty in Germany. Based on an approach that takes into account the possibility of multiple spells the results suggest that around $30 \%$ of current poverty was chronic in the sense that the affected individuals faced five or more periods in poverty over a period of ten years. Moreover, around $35 \%$ were in the midst of a long spell of at least five years and $33 \%$ of those just starting a fresh spell faced a career of chronic poverty.

With respect to the covariates of chronic poverty, employment status of the household head and the number of other earners were the most important correlates of long-term poverty. However, contrary to what one might expect from cross-sectional results, it was not so much unemployment (in the form of long-term unemployment) but non-employment that accompanied many chronic poverty experiences. This may have been non-employment as a result of a retreat from the labor market after an extended period of unemployment or just economic inactivity. An example for the latter case were lone parent households. These were over-represented among the chronic poor but, due to their small population share, they accounted only for a small part of the chronic poverty population. 
Also in contrast to cross-sectional findings, individuals from pensioner households constituted a considerable share of the chronic poor. This can be explained by the fact that, once poor, individuals from these households do not have many possibilities to change their situation. Also contrary to what is usually found in a cross-section, there seemed to be no significant association of longitudinal poverty status and a large number of children in the household. Finally, the estimates suggest that the risk of long-term poverty was completely absent if the household head had high educational qualifications.

Even in the case, where observed and unobserved characteristics were controlled for, poverty status depended on the time already spent in or out of poverty. Such a finding is consistent with the hypothesis that individuals who suffer long periods of poverty will get discouraged and therefore find it harder to escape their situation, e.g. by taking up a job. A similar mechanism could explain negative duration dependence of re-entry. The results also suggest that a small number of individuals (6\% of the population) had unfavourable unobserved characteristics that led to low exit and high re-entry rates, making these individuals likely candidates for chronic poverty.

It is interesting to compare these results with those in Devicienti (2001) for Britain (also compare Jenkins/Rigg (2001) for very similar results) and Stevens (1999) for the United States. ${ }^{22}$ While exit rates found here were comparable to those for Great Britain, the probability of re-entry seemed much lower in Germany than in Britain (e.g. $18 \%$ compared to $32 \%$ after the first year out of poverty). Poverty generally appeared to be more persistent in Britain. Although Devicienti (2001) used only information on eight years, the fraction of individuals in the sample who were poor five or more years out of ten was considerably higher than in Germany $(6 \%$ compared to $3 \%$ ). Also, $25 \%$ of those beginning a poverty spell in the British sample faced five or more years below the poverty line, compared to $16 \%$ in Germany. ${ }^{23}$ In contrast to Germany, the number of children in the household and the gender of the household head seemed to matter for long-term poverty in Britain. Finally, the population share of the group with unfavourable unobserved characteristics ('low/high'-type) was much larger in Devicienti's (2001) estimates (23\% compared to $6 \%$ in Germany).

\footnotetext{
${ }^{22} \mathrm{~A}$ direct comparison is difficult because the three studies use different income concepts, equivalence scales and poverty lines. However, income dynamics and results conditioning on poverty status are probably less affected than levels or unconditional estimates.

${ }^{23}$ However, the same number computed from exit and entry rates was comparable in both countries (32\% vs. $28 \%$ in Britain, see Table 1).
} 
A comparison with the results for the United States reveals that exit rates were almost identical in both countries, but that re-entry rates were considerably lower in Germany. This indicates that poverty in the United States was more persistent, which is confirmed by the much higher fraction of chronic poverty candidates among those just starting a poverty spell (35\% compared to $16 \%$ in the sample and $41 \%$ compared to $32 \%$ when calculated from exit and re-entry rates). As in Germany high-educational qualifications had a strong favorable effect on the probability of long-term poverty. The distribution of unobserved characteristics is difficult to compare since Stevens (1999) split up her sample in blacks and whites. However, as the share of white individuals with unfavorable unobserved characteristics was similar to that estimated for Germany and as such characteristics seemed very common among blacks, the share of the group with disadvantageous unobserved characteristics was probably higher in the United States than in Germany. 


\section{References}

Bane, M.J. and D.T. Ellwood (1986): Slipping into and out of Poverty: The Dynamics of Spells, Journal of Human Resources 21, pp. 1 - 23.

Becker, I. (1997): Die Entwicklung von Einkommensverteilung und Einkommensarmut in den alten Bundesländern von 1962 bis 1988, in Becker, I. and R. Hauser (1997)(eds.): Einkommensverteilung und Armut. Deutschland auf dem Weg zur Vierfünftelgesellschaft?, Campus Verlag, Frankfurt/M., pp. 43 - 61.

Biewen, M. (2002): The Covariance Structure of East and West German Incomes and its Implications for the Persistence of Poverty and Inequality, IZA Discussion Paper No. 459, Institute for the Study of Labor, Bonn.

Biewen, M. and S.P. Jenkins (2001): Who is most likely to be poor in Germany? in: Becker, I., N. Ott and G. Rolf (2001)(eds.): Soziale Sicherung in einer dynamischen Gesellschaft, Campus Verlag, Frankfurt/M., pp. 440 - 462.

Binder, D.A. (1983): On the Variances of Asymptotically Normal Estimators from Complex Sample Surveys, International Statistical Review 51, pp. 293 - 300.

Bundesministerium für Arbeit und Sozialordnung (2001): Lebenslagen in Deutschland, Der erste Armuts- und Reichtumsbericht der Bundesregierung, Berlin.

Deaton, A. (1997): The analysis of household surveys: a microeconometric approach to development policy, Johns Hopkins University Press, Baltimore.

Devicienti, F. (2001): Estimating Poverty Persistence in Britain, LABORatorio Riccardo Rivelli WP 2001-02, Torino.

Haisken-DeNew, J. and J. Frick (2001): Desktop-Companion to the German Socio-Economic Panel Study, Deutsches Institut für Wirtschaftsforschung (DIW), Berlin.

Hauser, R. (1997): Armut, Armutsgefährdung und Armutsbekämpfung in der Bundesrepublik Deutschland, Jahrbücher für Nationalökonomie und Statistik 216, pp. 525 - 548.

Heckman, J. (1981): The Incidental Parameter Problem and the Problem of Initial Conditions in Estimating a Discrete Time-Discrete Data Stochastic Process, in: Manski, C., D. McFadden (eds.): Structural Analysis of Discrete Data with Econometric Applications, Cambridge, MA, 
MIT Press, pp. 179 - 195.

Heckman, J. and B. Singer (1984): A Method for Minimising the Impact of Distributional Assumptions in Econometric Models of Duration Data, Econometrica 52, pp. 271 - 320.

Jenkins, S.P. and J.A. Rigg (2001): The Dynamics of Poverty in Britain, Department for Work and Pensions Research Report No. 157, Corporate Document Services, Leeds.

Krause, P. (2001): Einkommen in Deutschland - Entwicklung, Dynamik, permanente Verteilung und Redistribution, in: Becker, I., N. Ott and G. Rolf (2001)(eds.): Soziale Sicherung in einer dynamischen Gesellschaft, Campus Verlag, Frankfurt/M., pp. 418 - 439.

Meghir, C. and E. Whitehouse (1997): Labour market transitions and retirement of men in the UK, Journal of Econometrics 79, pp. 327 - 354.

Otto, B. and T. Siedler (2003): Armut in West- und Ostdeutschland - ein differenzierter Vergleich, DIW Wochenbericht 4/2003, pp. 61 - 66.

Oxley, H., T.T. Dang and Pablo Antonlin (2000): Poverty dynamics in six OECD countries, OECD Economic Studies 30, pp. 7 - 52.

Skinner, C.J., D. Holt and T.M.F. Smith (1989): Analysis of Complex Surveys, Chichester, Wiley.

SOEP-Group (2001): The German Socio-Economic Panel (GSOEP) after more than 15 years - Overview, in: Holst, E., D.R. Lillard and Th.A. DiPrete (eds.): Proceedings of the 2000 Fourth International Conference of German Socio-Economic Panel Study Users (GSOEP2000), Vierteljahreshefte zur Wirtschaftsforschung (Quarterly Journal of Economic Research) Vol. 70, pp. 7 - 14 .

Stevens, A.H. (1999): Climbing out of Poverty , Falling Back in. Measuring the Persistence of Poverty over Multiple Spells, Journal of Human Resources 34, pp. 557 -588. 


\section{$9 \quad$ Figures}

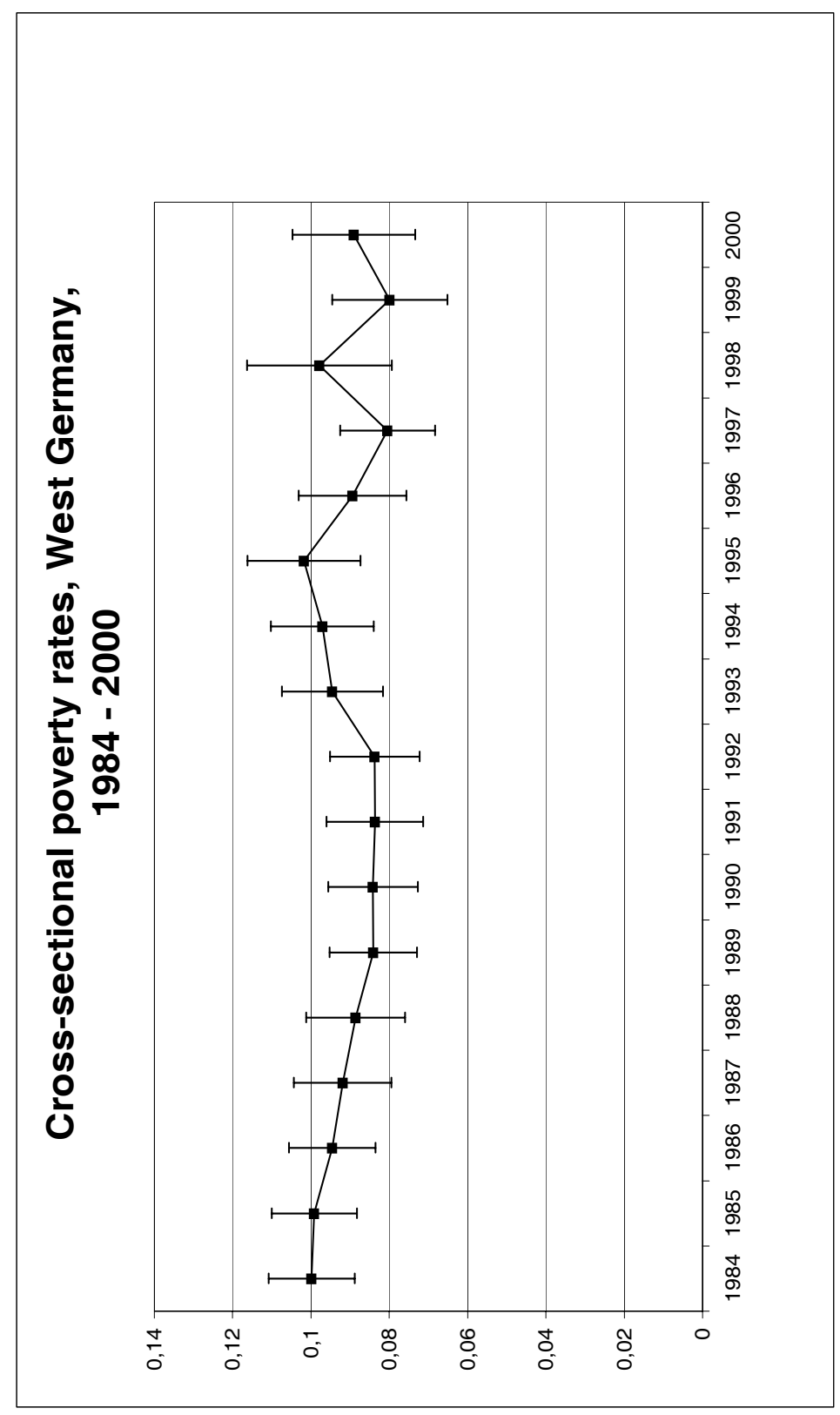

Figure 1: Cross-sectional poverty rates, West Germany 1984 - 2000 (Vertical bars show $95 \%$ confidence intervals) 


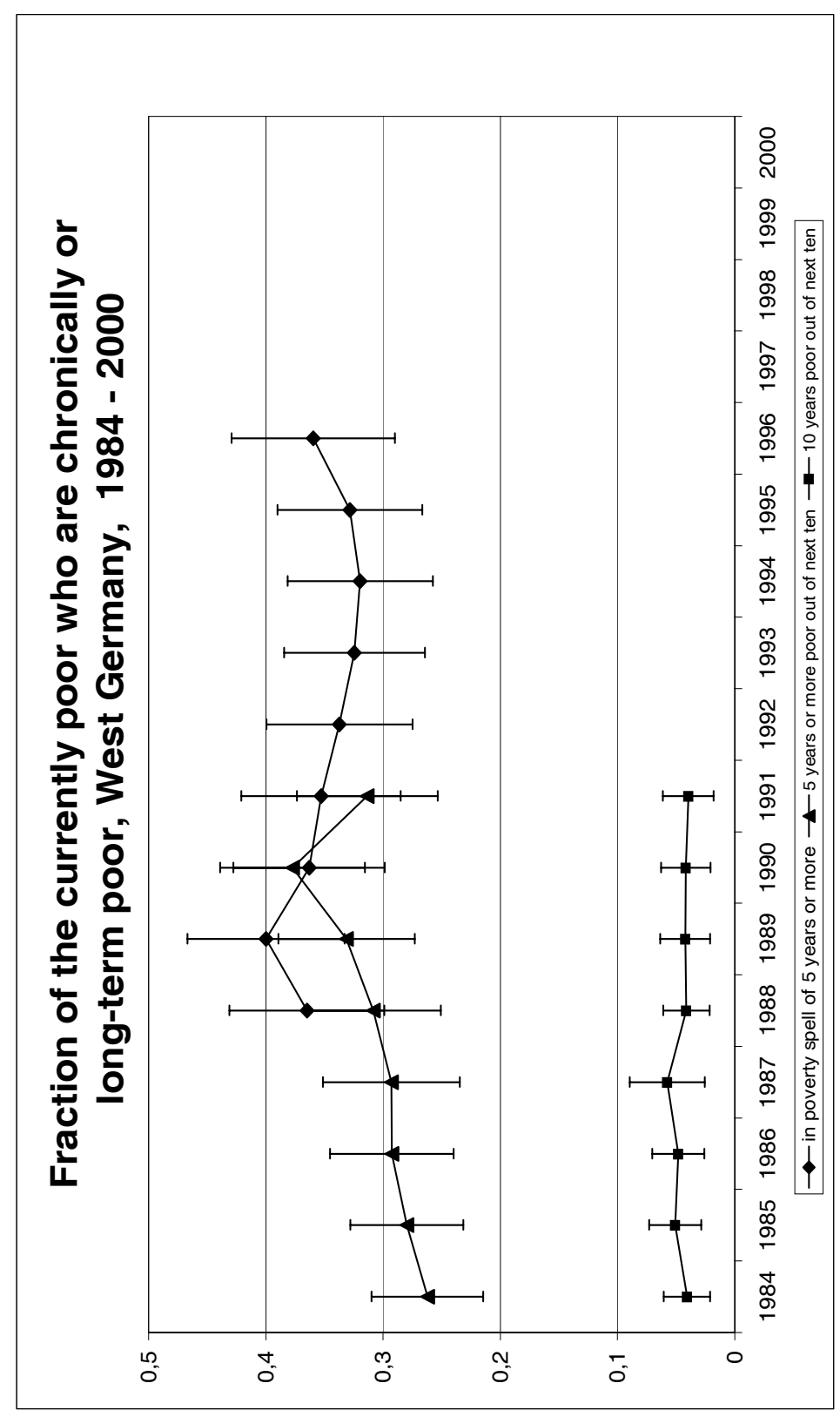

Figure 2: Fraction of chronic and long-term poverty, West Germany 1984 - 2000 (Vertical bars show $95 \%$ confidence intervals) 


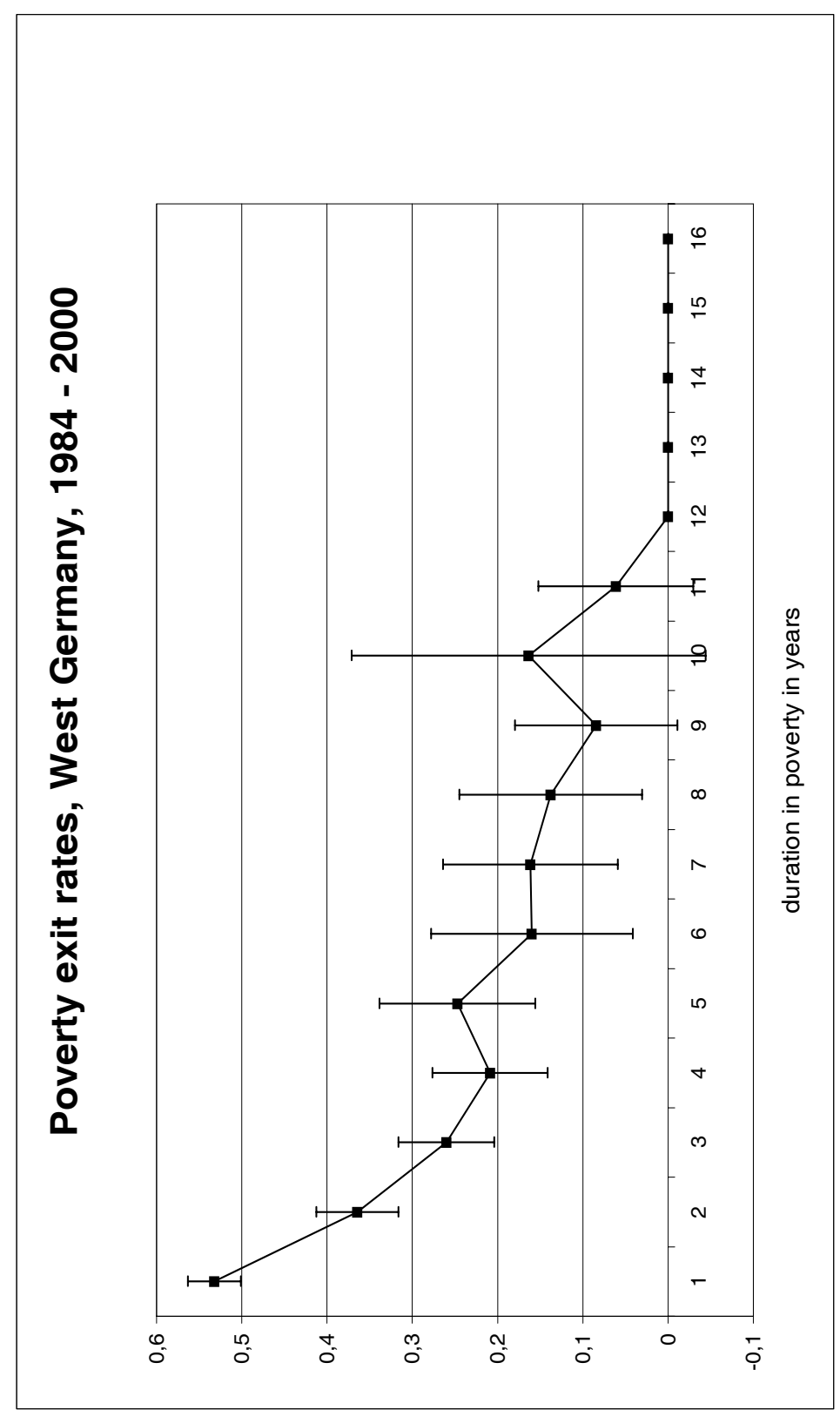

Figure 3: Poverty exit rates, West Germany 1984 - 2000

(Vertical bars show $95 \%$ confidence intervals) 


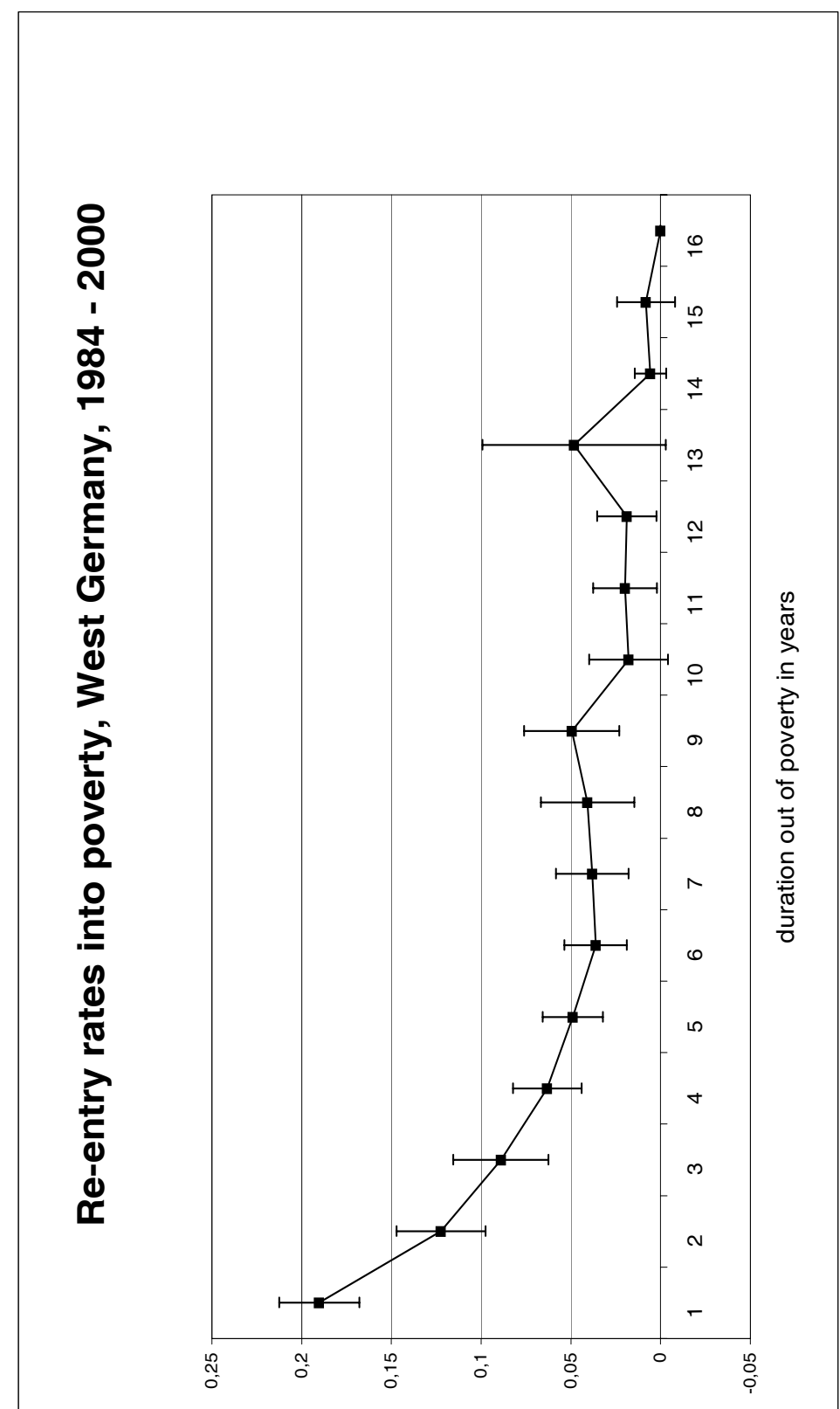

Figure 4: Poverty re-entry rates, West Germany 1984 - 2000

(Vertical bars show $95 \%$ confidence intervals) 


\section{Tables}

Table 1. Distribution of number of years spent poor out of the next ten for individuals just starting a poverty spell (Standard errors in parentheses ${ }^{a}$ )

\begin{tabular}{|c|c|c|c|c|}
\hline Number of years poor & Multiple spell ${ }^{b}$ & Single spell ${ }^{c}$ & Sample ${ }^{d}$ & \\
\hline 1 & 0.2730 & 0.5321 & 0.4529 & $(0.0218)$ \\
\hline 2 & 0.1840 & 0.1705 & 0.1847 & $(0.0165)$ \\
\hline 3 & 0.1265 & 0.0773 & 0.1225 & $(0.0136)$ \\
\hline 4 & 0.0917 & 0.0459 & 0.0781 & $(0.0107)$ \\
\hline 5 & 0.0776 & 0.0430 & 0.0433 & $(0.0066)$ \\
\hline 6 & 0.0585 & 0.0209 & 0.0362 & $(0.0070)$ \\
\hline 7 & 0.0473 & 0.0177 & 0.0171 & $(0.0039)$ \\
\hline 8 & 0.0381 & 0.0127 & 0.0164 & $(0.0049)$ \\
\hline 9 & 0.0300 & 0.0067 & 0.0319 & $(0.0112)$ \\
\hline 10 & 0.0729 & 0.0729 & 0.0164 & $(0.0038)$ \\
\hline Average years poor out of 10 & 3.7612 & 2.6438 & 2.6379 & - \\
\hline Share of $\geq 5$ years poor ${ }^{e}$ & 0.6312 & 0.5126 & 0.4305 & - \\
\hline
\end{tabular}

${ }^{a}$ Standard errors account for clustering of individuals in households

${ }^{b}$ Using estimated exit and re-entry rates

${ }^{c}$ Using estimated exit rates

${ }^{d}$ Individuals starting a poverty spell in 1984 - 1990, longitudinally weighted data

${ }^{e}$ Person-year share of those 5 or more years poor

Table 2. Distribution of number of years

spent poor out of the next ten, whole population ${ }^{a}$

(Standard errors in parentheses ${ }^{b}$ )

\begin{tabular}{|l|ll|ll|r|}
\hline Number of years poor & $1984-93$ & & $1991-2000$ & $2000-09^{c}$ \\
\hline 0 & 0.7736 & $(0.0053)$ & 0.8283 & $(0.0049)$ & 0.7575 \\
1 & 0.1104 & $(0.0037)$ & 0.0797 & $(0.0031)$ & 0.0745 \\
2 & 0.0477 & $(0.0025)$ & 0.0377 & $(0.0022)$ & 0.0466 \\
3 & 0.0257 & $(0.0018)$ & 0.0185 & $(0.0014)$ & 0.0302 \\
4 & 0.0155 & $(0.0013)$ & 0.0117 & $(0.0012)$ & 0.0216 \\
5 & 0.0090 & $(0.0010)$ & 0.0085 & $(0.0010)$ & 0.0170 \\
6 & 0.0064 & $(0.0009)$ & 0.0060 & $(0.0009)$ & 0.0131 \\
7 & 0.0043 & $(0.0007)$ & 0.0035 & $(0.0006)$ & 0.0098 \\
8 & 0.0029 & $(0.0005)$ & 0.0021 & $(0.0005)$ & 0.0076 \\
9 & 0.0028 & $(0.0006)$ & 0.0024 & $(0.0004)$ & 0.0062 \\
10 & 0.0012 & $(0.0002)$ & 0.0011 & $(0.0003)$ & 0.0154 \\
\hline Average years poor out of 10 & 0.5212 & - & 0.4127 & - & 0.8506 \\
\hline Share of $\geq 5$ years poor ${ }^{d}$ & 0.3375 & 0.3751 & 0.5943 \\
\hline
\end{tabular}


Table 3a. Chronic poverty and household types (Standard errors in parentheses ${ }^{a}$ )

\begin{tabular}{|c|c|c|c|c|c|c|c|c|c|}
\hline \multirow{2}{*}{$\begin{array}{l}\text { Type } \\
\text { Female household head }\end{array}$} & \multicolumn{2}{|c|}{ all individuals ${ }^{b}$} & \multirow{2}{*}{$\begin{array}{l}\text { aspect } \\
\text { at spell beginning } \\
\text { always when poor } \\
80-100 \% \text { of time } \\
50-80 \% \text { of time }\end{array}$} & \multicolumn{2}{|c|}{ spells $\geq 5$ years $^{c}$} & \multicolumn{2}{|c|}{$\geq 5 / 10$ years poor ${ }^{d}$} & \multicolumn{2}{|c|}{$10 / 10$ years poor ${ }^{d}$} \\
\hline & 0.2019 & $(0.0048)$ & & $\begin{array}{r}0.5032 \\
- \\
0.4984 \\
0.0329 \\
\end{array}$ & $\begin{array}{r}(0.0421) \\
- \\
(0.0422) \\
(0.0127) \\
\end{array}$ & $\begin{array}{r}- \\
0.5229 \\
0.3521 \\
0.2064 \\
\end{array}$ & $\begin{array}{r}- \\
(0.0426) \\
(0.0369) \\
(0.0358) \\
\end{array}$ & $\begin{array}{r}- \\
0.6632 \\
0.6632 \\
0.0397 \\
\end{array}$ & $\begin{array}{l}- \\
(0.1361) \\
(0.1361) \\
(0.0396) \\
\end{array}$ \\
\hline$\#$ workers $=0$ & 0.1776 & $(0.0036)$ & $\begin{array}{l}\text { at spell beginning } \\
\text { always when poor } \\
80-100 \% \text { of time } \\
50-80 \% \text { of time }\end{array}$ & $\begin{array}{r}0.7051 \\
- \\
0.6615 \\
0.0980\end{array}$ & $\begin{array}{r}(0.0420) \\
- \\
(0.0421) \\
(0.0245)\end{array}$ & $\begin{array}{r}- \\
0.5263 \\
0.3321 \\
0.3529\end{array}$ & $\begin{array}{l}- \\
(0.0433) \\
(0.0358) \\
(0.0403)\end{array}$ & $\begin{array}{r}- \\
0.6676 \\
0.8452 \\
0.0131\end{array}$ & $\begin{array}{l}- \\
(0.1362) \\
(0.1043) \\
(0.0134)\end{array}$ \\
\hline$\#$ workers $=1$ & 0.4485 & $(0.0045)$ & $\begin{array}{l}\text { at spell beginning } \\
\text { always when poor } \\
80-100 \% \text { of time } \\
50-80 \% \text { of time }\end{array}$ & $\begin{array}{r}0.2413 \\
- \\
0.1412 \\
0.0611 \\
\end{array}$ & $\begin{array}{r}(0.0378) \\
- \\
(0.0327) \\
(0.0180) \\
\end{array}$ & $\begin{array}{r}- \\
0.0723 \\
0.0652 \\
0.1356 \\
\end{array}$ & $\begin{array}{r}- \\
(0.0231) \\
(0.0188) \\
(0.0315) \\
\end{array}$ & $\begin{array}{r}- \\
0 \\
0.0325 \\
0\end{array}$ & $\begin{array}{r}- \\
(0) \\
(0.0327) \\
(0) \\
\end{array}$ \\
\hline$\#$ workers $=2$ & 0.3110 & $(0.0043)$ & $\begin{array}{l}\text { at spell beginning } \\
\text { always when poor } \\
80-100 \% \text { of time } \\
50-80 \% \text { of time }\end{array}$ & $\begin{array}{r}0.0535 \\
- \\
0.0336 \\
0.0168 \\
\end{array}$ & $\begin{array}{r}(0.0232) \\
- \\
(0.0183) \\
(0.0097) \\
\end{array}$ & $\begin{array}{r}- \\
0.0247 \\
0.0413 \\
0.0196 \\
\end{array}$ & $\begin{array}{r}- \\
(0.0151) \\
(0.0218) \\
(0.0113) \\
\end{array}$ & $\begin{array}{r}- \\
0 \\
0 \\
0.1090 \\
\end{array}$ & $\begin{array}{r}- \\
(0) \\
(0) \\
(0.1010) \\
\end{array}$ \\
\hline$\#$ workers $\geq 3$ & 0.0627 & $(0.0025)$ & $\begin{array}{l}\text { at spell beginning } \\
\text { always when poor } \\
80-100 \% \text { of time } \\
50-80 \% \text { of time }\end{array}$ & $\begin{array}{l}0 \\
- \\
0 \\
0\end{array}$ & $\begin{array}{r}(0) \\
- \\
(0) \\
(0)\end{array}$ & $\begin{array}{r}- \\
0 \\
0 \\
0.0019 \\
\end{array}$ & $\begin{array}{r}- \\
(0) \\
(0) \\
(0.0019) \\
\end{array}$ & $\begin{array}{l}- \\
0 \\
0 \\
0\end{array}$ & $\begin{array}{l}- \\
(0) \\
(0) \\
(0)\end{array}$ \\
\hline single adult & 0.2166 & $(0.0021)$ & $\begin{array}{l}\text { at spell beginning } \\
\text { always when poor } \\
80-100 \% \text { of time } \\
50-80 \% \text { of time }\end{array}$ & $\begin{array}{r}0.2999 \\
- \\
0.3241 \\
0.0225 \\
\end{array}$ & $\begin{array}{r}(0.0334) \\
- \\
(0.0366) \\
(0.0093) \\
\end{array}$ & $\begin{array}{r}- \\
0.2883 \\
0.2304 \\
0.1205 \\
\end{array}$ & $\begin{array}{r}- \\
(0.0345) \\
(0.0310) \\
(0.0229) \\
\end{array}$ & $\begin{array}{r}- \\
0.4717 \\
0.4717 \\
0.1380 \\
\end{array}$ & $\begin{array}{r}- \\
(0.1364) \\
(0.1364) \\
(0.0978) \\
\end{array}$ \\
\hline 2 adults & 0.2166 & $(0.0041)$ & $\begin{array}{l}\text { at spell beginning } \\
\text { always when poor } \\
80-100 \% \text { of time } \\
50-80 \% \text { of time }\end{array}$ & $\begin{array}{r}0.1804 \\
- \\
0.1064 \\
0.0268 \\
\end{array}$ & $\begin{array}{r}(0.0297) \\
- \\
(0.0217) \\
(0.0106) \\
\end{array}$ & $\begin{array}{r}- \\
0.0845 \\
0.0607 \\
0.0671\end{array}$ & $\begin{array}{r}- \\
(0.0212) \\
(0.0182) \\
(0.0179) \\
\end{array}$ & $\begin{array}{r}- \\
0.0579 \\
0.0579 \\
0\end{array}$ & $\begin{array}{r}- \\
(0.0567) \\
(0.0567) \\
(0) \\
\end{array}$ \\
\hline single parent & 0.0237 & $(0.0013)$ & $\begin{array}{l}\text { at spell beginning } \\
\text { always when poor } \\
80-100 \% \text { of time } \\
50-80 \% \text { of time }\end{array}$ & $\begin{array}{r}0.1637 \\
- \\
0.1373 \\
0.0591 \\
\end{array}$ & $\begin{array}{r}(0.0280) \\
- \\
(0.0313) \\
(0.0175) \\
\end{array}$ & $\begin{array}{r}- \\
0.0964 \\
0.0474 \\
0.1066 \\
\end{array}$ & $\begin{array}{r}- \\
(0.0321) \\
(0.0182) \\
(0.0339) \\
\end{array}$ & $\begin{array}{r}- \\
0.2101 \\
0.2101 \\
0.0982 \\
\end{array}$ & $\begin{array}{l}- \\
(0.1180) \\
(0.1180) \\
(0.0921)\end{array}$ \\
\hline couple with children & 0.3712 & $(0.0052)$ & $\begin{array}{l}\text { at spell beginning } \\
\text { always when poor } \\
80-100 \% \text { of time } \\
50-80 \% \text { of time }\end{array}$ & $\begin{array}{r}0.2854 \\
- \\
0.1613 \\
0.0731 \\
\end{array}$ & $\begin{array}{r}(0.0429) \\
- \\
(0.0298) \\
(0.0265)\end{array}$ & $\begin{array}{r}- \\
0.1017 \\
0.1042 \\
0.1019 \\
\end{array}$ & $\begin{array}{r}- \\
(0.0246) \\
(0.0246) \\
(0.0220)\end{array}$ & $\begin{array}{r}- \\
0.0131 \\
0.0131 \\
0\end{array}$ & $\begin{array}{r}- \\
(0.0134) \\
(0.0134) \\
(0)\end{array}$ \\
\hline larger households & 0.3016 & $(0.0050)$ & $\begin{array}{l}\text { at spell beginning } \\
\text { always when poor } \\
80-100 \% \text { of time } \\
50-80 \% \text { of time }\end{array}$ & $\begin{array}{r}0.0703 \\
- \\
0.0725 \\
0.0203 \\
\end{array}$ & $\begin{array}{r}(0.0211) \\
- \\
(0.0243) \\
(0.0087)\end{array}$ & $\begin{array}{r}- \\
0.0544 \\
0.0491 \\
0.0516 \\
\end{array}$ & $\begin{array}{r}- \\
(0.0201) \\
(0.0197) \\
(0.0262)\end{array}$ & $\begin{array}{r}- \\
0.1090 \\
0.1090 \\
0\end{array}$ & $\begin{array}{r}- \\
(0.1010) \\
(0.1010) \\
(0)\end{array}$ \\
\hline head employed & 0.7075 & $(0.0048)$ & $\begin{array}{l}\text { at spell beginning } \\
\text { always when poor } \\
80-100 \% \text { of time } \\
50-80 \% \text { of time }\end{array}$ & $\begin{array}{r}0.2162 \\
- \\
0.1370 \\
0.0450\end{array}$ & $\begin{array}{r}(0.0384) \\
- \\
(0.0331) \\
(0.0165) \\
\end{array}$ & $\begin{array}{r}- \\
0.1084 \\
0.1187 \\
0.0753 \\
\end{array}$ & $\begin{array}{r}- \\
(0.0288) \\
(0.0290) \\
(0.0208)\end{array}$ & $\begin{array}{r}- \\
0 \\
0.0325 \\
0.1090 \\
\end{array}$ & $\begin{array}{r}- \\
(0) \\
(0.0327) \\
(0.1010) \\
\end{array}$ \\
\hline head unemployed & 0.0480 & $(0.0020)$ & $\begin{array}{l}\text { at spell beginning } \\
\text { always when poor } \\
80-100 \% \text { of time } \\
50-80 \% \text { of time }\end{array}$ & $\begin{array}{r}0.1734 \\
- \\
0.0759 \\
0.1310 \\
\end{array}$ & $\begin{array}{r}(0.0297) \\
- \\
(0.0184) \\
(0.0282) \\
\end{array}$ & $\begin{array}{r}- \\
0.0576 \\
0.0217 \\
0.0932 \\
\end{array}$ & $\begin{array}{r}- \\
(0.0147) \\
(0.0081) \\
(0.0207)\end{array}$ & $\begin{array}{r}- \\
0 \\
0 \\
0.1731 \\
\end{array}$ & $\begin{array}{r}- \\
(0) \\
(0) \\
(0.1057) \\
\end{array}$ \\
\hline head retired & 0.1658 & $(0.0040)$ & $\begin{array}{l}\text { at spell beginning } \\
\text { always when poor } \\
80-100 \% \text { of time } \\
50-80 \% \text { of time }\end{array}$ & $\begin{array}{r}0.3191 \\
- \\
0.3270 \\
0.0713 \\
\end{array}$ & $\begin{array}{r}(0.0371) \\
- \\
(0.0371) \\
(0.0199)\end{array}$ & $\begin{array}{r}- \\
0.2810 \\
0.2404 \\
0.1519 \\
\end{array}$ & $\begin{array}{r}- \\
(0.0358) \\
(0.0321) \\
(0.0271)\end{array}$ & $\begin{array}{r}- \\
0.3765 \\
0.5694 \\
0 \\
\end{array}$ & $\begin{array}{r}- \\
(0.1275) \\
(0.1400) \\
(0)\end{array}$ \\
\hline head other & 0.0785 & $(0.0025)$ & $\begin{array}{l}\text { at spell beginning } \\
\text { always when poor } \\
80-100 \% \text { of time } \\
50-80 \% \text { of time }\end{array}$ & $\begin{array}{r}0.2911 \\
- \\
0.1587 \\
0.0535\end{array}$ & $\begin{array}{r}(0.0375) \\
- \\
(0.0324) \\
(0.0157)\end{array}$ & $\begin{array}{r}- \\
0.0931 \\
0.0592 \\
0.1351\end{array}$ & $\begin{array}{r}- \\
(0.0313) \\
(0.0194) \\
(0.0335)\end{array}$ & $\begin{array}{r}- \\
0 \\
0.1157 \\
0\end{array}$ & $\begin{array}{r}- \\
(0) \\
(0.1063) \\
(0)\end{array}$ \\
\hline
\end{tabular}

\footnotetext{
a Standard errors account for clustering of individuals in households, longitudinally weighted data

$b$ Pooled sample 1984-2000

c $1984-2000$

d 1991-2000, results for 1984-1993 very similar

${ }^{e}$ Individual lives in household of given type during 80-100\% of total spell length (column 4) or of 10 years (columns 5 and 6 )

${ }^{f}$ Individual lives in household of given type during 50-80\% of total spell length (column 4) or of 10 years (columns 5 and 6 )
} 
Table 3b. Chronic poverty and household types (Standard errors in parentheses ${ }^{a}$ )

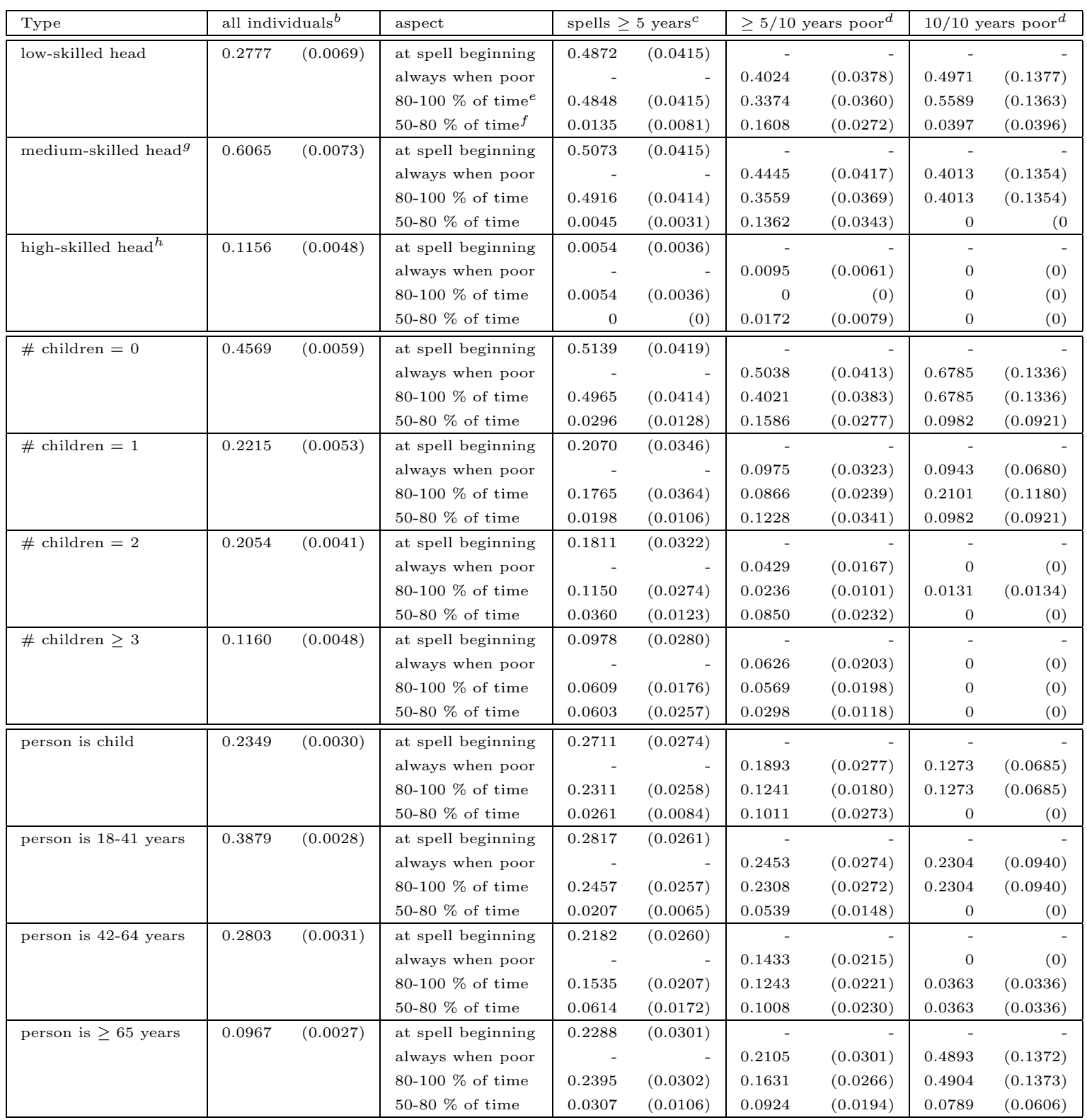

\footnotetext{
${ }^{a}$ Standard errors account for clustering of individuals in households, longitudinally weighted data

$b$ Pooled sample 1984-2000

c $1984-2000$

${ }^{d}$ 1991-2000, results for 1984-1993 very similar

${ }^{e}$ Individual lives in household of given type during 80-100\% of total spell length (column 4) or of 10 years (columns 5 and 6 )

${ }^{f}$ Individual lives in household of given type during 50-80\% of total spell length (column 4 ) or of 10 years (columns 5 and 6 )

$g$ Abitur or Lehre (vocational training)

$h$ University degree
} 
Table 4. Hazard model estimates ${ }^{a}$

(Standard errors in parentheses ${ }^{b}$ )

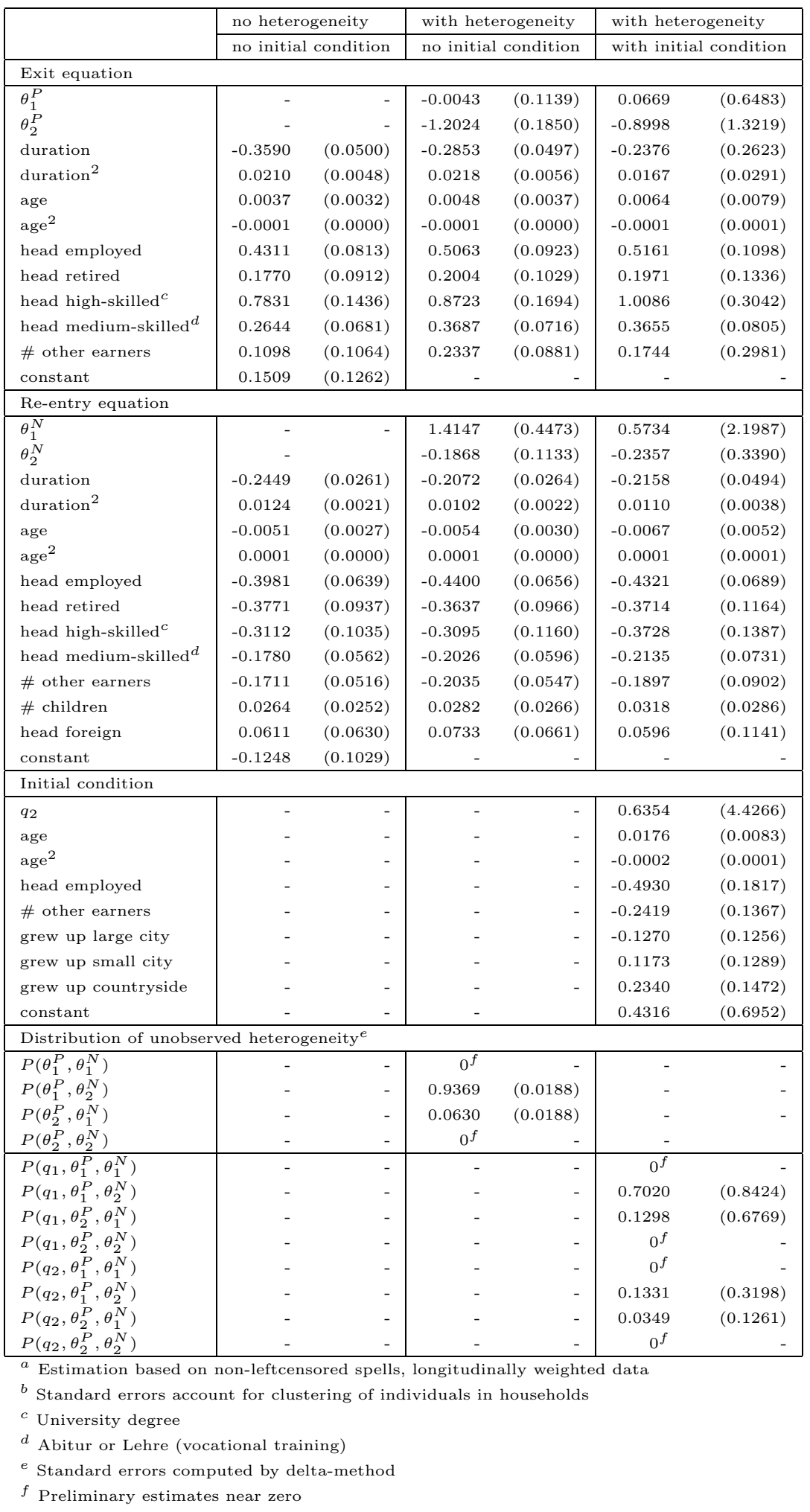


Table 5a. Average number of years spent poor

out of the next ten for individuals just starting a poverty spell ${ }^{a}$

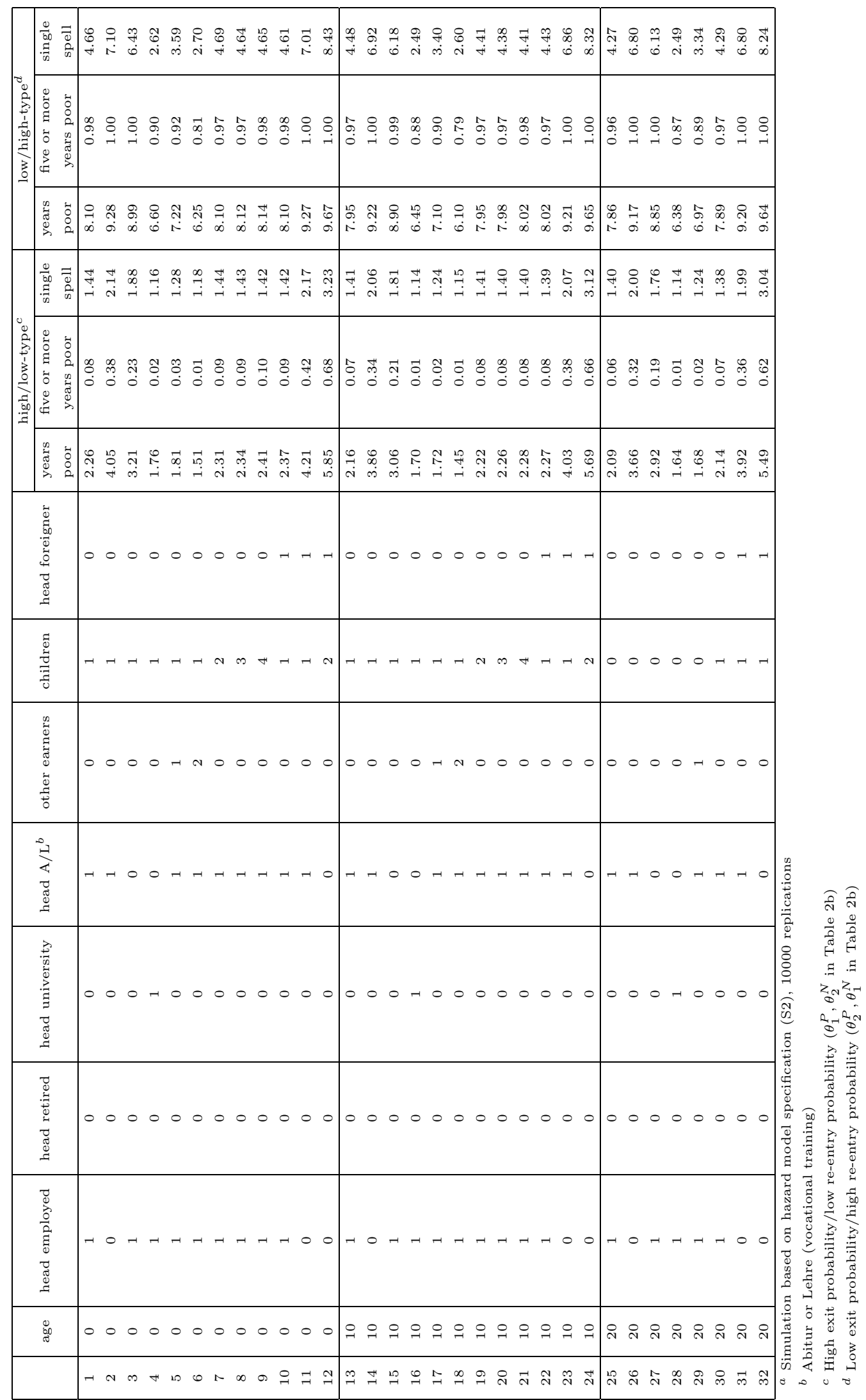


Table 5b. Average number of years spent poor

out of the next ten for individuals just starting a poverty spell

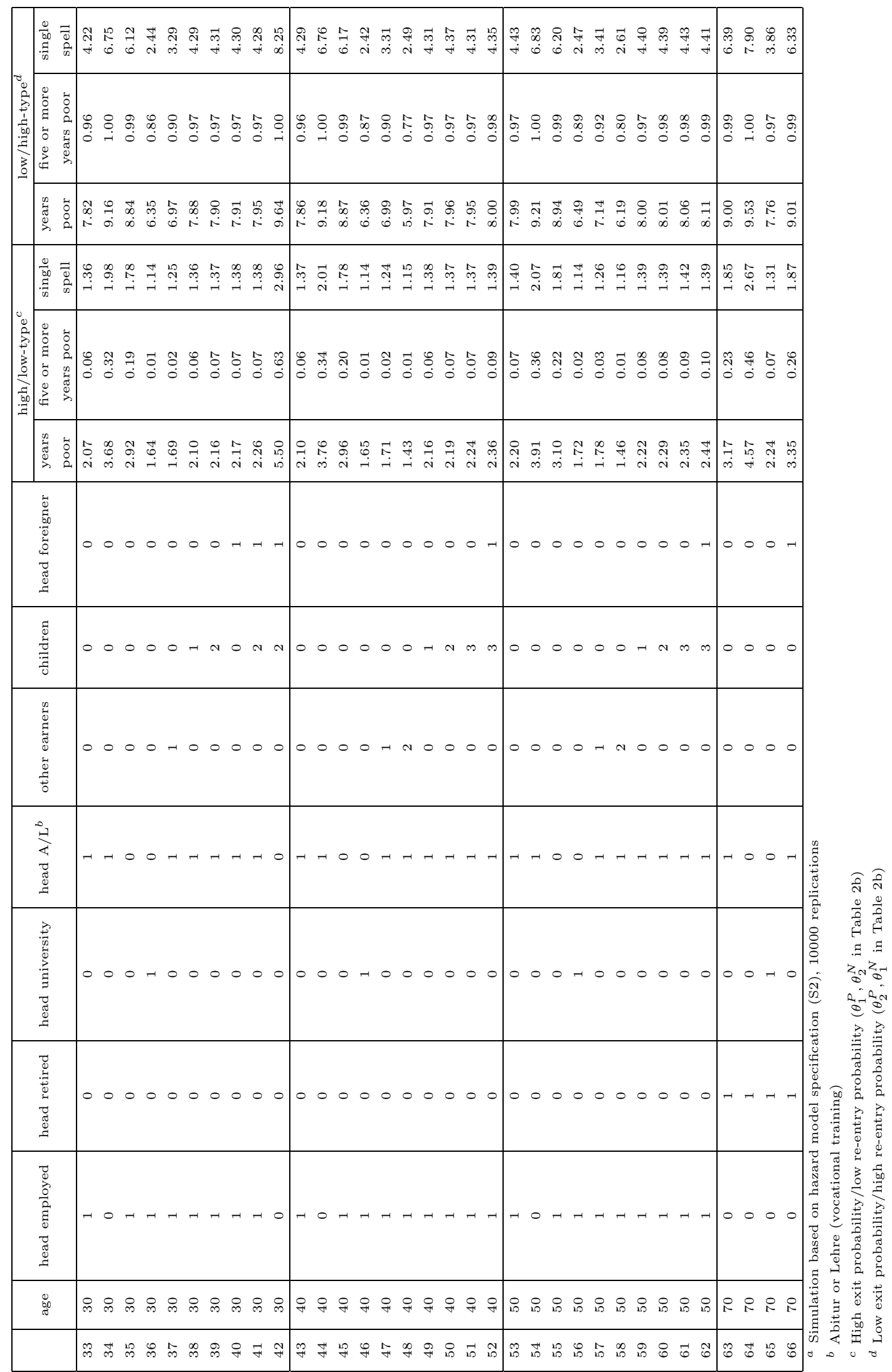

